\title{
高次電流重畳による電動機の半径方向加振力低減*
}

\author{
屋 代 春 樹*1, 高 田 \\ 一*2

\section{Reduction of a Radial Electromagnetic Oscillating Force of an Electrical Motor by Superposing a High Order Current} \\ Haruki YASHIRO*3 and Hajime TAKADA \\ ${ }^{* 3}$ Technology Research Lab. No. 3 Nissan Research Centre Nissan Motor Co. Ltd., \\ 1 Natsushima, Yokosuka-shi, Kanagawa, 237-8523 Japan

\begin{abstract}
It is important to reduce the vibrations of an Interior Permanent Magnetic motor that is generally installed in electrical vehicles, fuel cell vehicles, and hybrid electrical vehicles. The purpose of the study here is to build up the reduction methodology of the radial oscillating force that causes the radiation noise from the surface of the motor case by controlling the working currents on IPM moror. The distributed winding IPM motor with 48 teeth on the stator and 4 pairs of poles on the rotor is treated. The relating equation between the radial force towards the stator and three phase alternating currents is provided firstly, utilizing the radial force that results from the Finite Element Analysis of the plane electromagnetic field. Secondly, high order currents are derived from the equation and superposed on the basic currents in order to reduce the radial oscillating force. Finally, the plane electromagnetic field analysis is performed again with the currents including the high order ones and a radial oscillating force reduction of about $20 \mathrm{~dB}$ with a torque increase of $2.8 \%$ is obtained.
\end{abstract}

Key Words : Electromagnetic Induced Vibration, Identification, Fast Fourier Transform, Automobile, Finite Element Method

\section{1. 緒 論}

地球環境問題が深刻化するにともない，ハイブリ ッド車両が普及し, 燃料電池車のリースが始まった. また, 電気自動車も見直されてきている.これらの車 両は, 通常の内燃機関の自動車とは異なり, 車両を駆 動するモータを有している.

自動車用車両駆動モー夕は, 高回転の機械強度が 有利などの理由により埋込磁石構造電動機（以下 IPM モータ）が主流となっている. IPM モータは上記特長 の反面, 磁石間鉄部の磁束の粗密差が大きくなって, トルクリプルや半径方向加振力が大きくなり, 振動騒 音の問題を引起こす特徴もある. 半径方向加振力は, ステータコア, モータケースの円環モードを励起し て, モータケースから発生する金属音のような放射音 の主要因となる. この放射音に関する研究は，今まで にも多く発表されてきた. 塩幡(1), 石橋(2らは, 円噮 モードと半径方向加振力の空間モードの関係から寄与 の高い加振力モードを見出し, その加振力で放射音計 算を実施して実験と良好な対応を得ている. ステータ

* 原稿受付 2005 年 6 月 16 日.

*1 正員, フェロー, 日産自動車(株) 237-8523 横須賀市夏島 町 1).

*2 正員, 横浜国立大学大学院工学研究院 (-240-8501 横浜市 保土ヶ谷区常盤台 79-5).

E-mail : h-yashiro@ mail.nissan.co.jp
突極とロー夕極の対向面積を减らすことで，半径方向 加振力を低减するという考えのもと，真田ら(の) SR モータを対象に，小林ら(4)は集中巻 IPMSM を対象に, ロータ表面に空隙を設けて，その効果を実験で確認し ている. 浅野らは, 磁界解析結果のマクスウェルの 応力を詳細に分析して, ティースの回転方向後端部の ギャップを拡大することで, 半径方向の応力を低减可 能なことを実験でも確認している.

このように, 磁界解析, 放射音解析の精度が向上 し, 構造体において種々の半径方向加振力低减研究報 告がある中で, ここでは, 基本電流に高次電流を重畳 することで半径方向加振力を低减する方法とその効果 について，計算による検討結果を報告する．以下，ま ず対象とする円環モードを記述する. 次に, 二次元有 限要素法磁界解析結果の半径方向力を使って, モータ を駆動する三相交流電流と半径方向力の関係式を導く. そして，その式をもとに対象とする半径方向加振力低 減のための高次電流を定式化する. 最後に, 高次電流 を基本電流に重畳して，あらためて二次元有限要素法 磁界解析を実施し, 半径方向加振力が低减しているの を確認する. なお, 有限要素法による磁界解析は, 電 磁界解析用ソフト JMAG（株式会社日本総合研究所 製）を使用した。 


\section{2 低減対象の半径方向加振力}

21 対象とする円環モード＼cjkstart前述のように, 放 射音にはモータの円環モードが大きく関与している. そこで, 有限要素法によるステータの二次元固有值解 析を実施した。代表的な固有モードをオリジナルのモ デル形状とともに図1に示寸，それぞれ，(a)は円環 2 次，(b)は円環 3 次，(c)は円環 0 次モードである. モー ドシェイプから円環 0 次が最も放射音になりやすいこ とは容易に想像できる. 実際のモータでは, ステータ をその外周で支えているモータケース上に，車体に設 置するためのブラケットなどが設定されるので, 純粋 な円環 0 次ではないが，それに近いモードシェイプの 放射音は大きくなるのが通常である. そこで，ここで は円環 0 次を対象モードとする.

22 対象とする半径方向加振力 有限要素法に よる磁界解析に使用したモー夕の計算モデルを図 2 に 示寸，ロー夕には反時計方向に回転を与えている. 図 2 は，三相交流電流（以下，基本電流）により駆動す る 4 極対, 分布巻 48 ティース IPMモー夕の $1 / 4$ モデル で, 節点数は 4212, 要素数は 3984 である. 1/4 モデル であるが，4 極対なので機械角 $90^{\circ}$ 回転で電気角は $360^{\circ}$ となる。これ以降, 図において, 横軸が Angle(deg)の場合は電気角を意味する. 基本電流 $900 \mathrm{~A}$

(片振幅) を印加した時のティース(2)の半径方向力 計算結果とそれをフーリエ変換後にデシベル表示した ものを図 3 に示寸. 半径方向力は, 図 3 上図に示寸よ うにティースのロータ側先端中央部での半径方向要素 節点力としており，外向きを正とした. 図 3 下図から わかるように, 半径方向力はモータの中心に向かって いて, 4 つのピーク（中心向き, マイナス）を有して いる. 図 4 の横軸は電気角に対寸る次数を示寸. 半径 方向力変動（半径方向加振力. 以下, 単に加振力) は, 電気角の偶数次数が大きいのが特徴である. 加振力は,

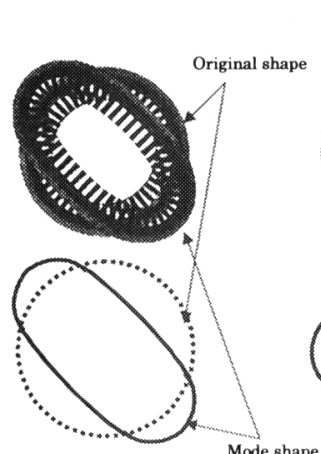

(a) $949 \mathrm{~Hz}$

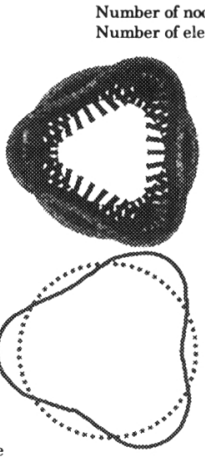

(b) $2475 \mathrm{~Hz}$

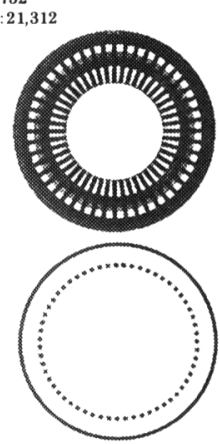

(c) $6254 \mathrm{~Hz}$
ロータとステータのティース間の磁力変動により発生 するもので, 永久磁石起因と電流（電磁石）起因から なる. 電流が印加されない場合（以下，無負荷時）は, ロータ回転に伴いロータに埋込まれた永久磁石とティ 一ス間の磁力変動により発生する（永久磁石起因）。

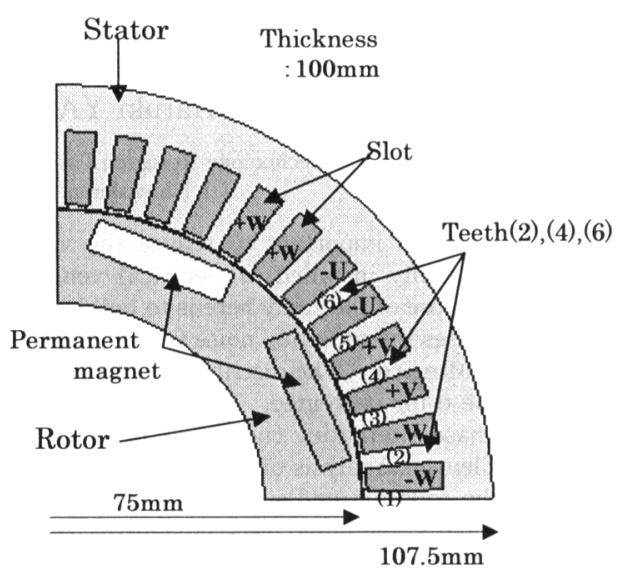

Fig.2 Two dimensional typical IPM motor
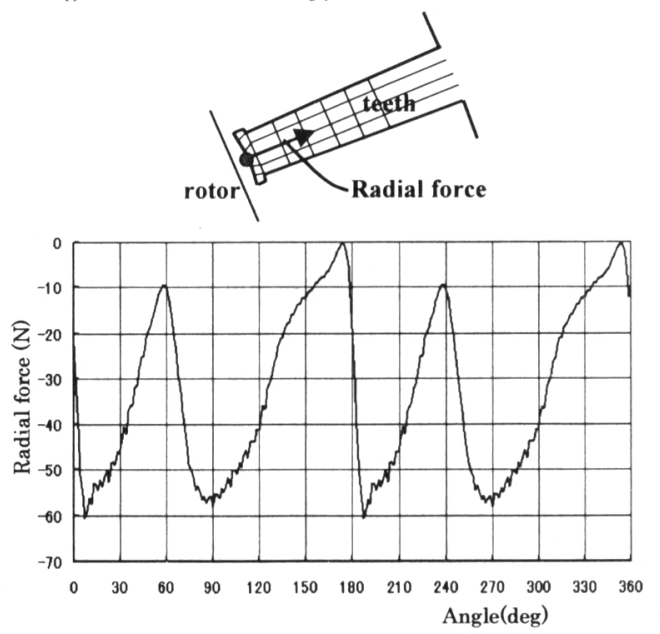

Fig.3 Radial force at the œnter of teeth(2)

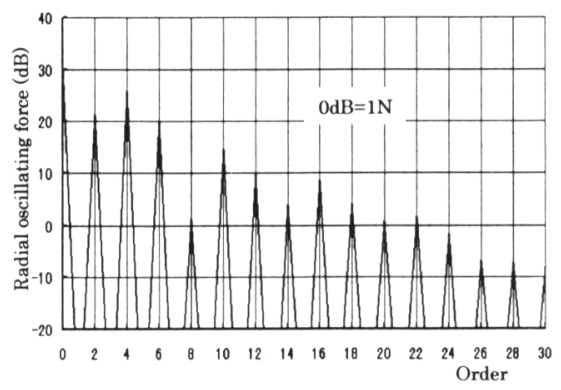

Fig.4 Radial oscillating force at the center of teeth(2)

Fig.1 Typical circular modes of stator. 
これは, 円周方向におけるコギングトルクに対応する. また, 電流が印加された場合は, 永久磁石起因に加え, ロータの電磁銅板部とステータの電磁石間の磁力変動 により加振力が発生する（電流起因）。これは, 円周 方向におけるリラクタンストルクの変動に対応するも のである.

次に, この節の主題である円環 0 次モードを励起し やすい加振力について検討する. 図 2 に示すティース (2)，(4)，(6)について, 半径方向力をフーリエ変換 した後の 2 次, 4 次, 6 次の実部を横軸に, 虚部を縦 軸に表示した結果を図 5 に示寸. 2, 4 次については 3 つティースの加振力の位相差が $120^{\circ} ， 240^{\circ}$ で, それ らの合力はほとんど 0 となるのに対し，6 次は各ティ 一スの加振力がほぼ同相である. ここでは示さないが, 両側スロット部を異なる相の電流が流れるティース (1)，(3)，(5)の組合せでもティース間の位相関係は 同様である. しかも, ティース(1)〜 (6)の 6 次はほぼ 同相である. このことから機械角 $360^{\circ}$ においても, 電気角 2 次, 4 次の加振力は円環 0 次モードを励起し にくく, 電気角 6 次の加振力は円環 0 次モードを励起 しやすいということになる. 電気角 8 次, 10 次, 12 次でも同様であり, 結局 6 の整数倍次数が円環 0 次モ 一ドを励起しやすく, 本報告の低减対象次数となる.

\section{3 半径方向力の数式表現 加振力を低减する} 高次電流を求めるには, 電流と半径方向力の関保を求 める必要があるが，今までにそれが示された例はなく， ここでは, 筆者らがトルクリプル低减で試みた方法(の) を適用する. すなわち, U相, $\mathrm{V}$ 相, $\mathrm{W}$ 相の電流をそ れぞれ $I_{w}, I_{v} I_{w}$ として, 半径方向力 $F\left(I_{u}, I_{v}, I_{w}\right)$ を下式 のように各相電流の多項式で表す.

$F\left(I_{u}, I_{v}, I_{w}\right)=G_{u} I_{u}+G_{v} I_{v}+G_{w} I_{w}+G_{u v} I_{u} I_{v}$
$+G_{v w} I_{v} I_{w}+G_{w u} I_{w} I_{u}+G_{u v w} I_{u} I_{v} I_{w}$
ここで, $G_{u}, G_{v}, G_{w}, \cdots$ ははそれぞれモー夕固有の特 性を示す係数で, 電気角の関数である. 式(1)の右辺 は, 基本電流を印加した場合には, 各相電流単独の第 1〜3 項ばかりでなく，2つの電流間で相互作用がある
と考えて第 4 6 項を加え, さらに 3 つの電流間でも 相互作用があると考え第 7 項を加えたものである. 式 (1)は電流起因の半径方向力を示す式であり, 永久磁 石起因（無負荷時）の半径方向力を含まない.つまり， $I_{u}=I_{v}=I_{w}=0$ とすると, $F\left(I_{u}, I_{v}, I_{w}\right)=0$ となる. $900 \mathrm{~A} の$ 基 本電流を印加した場合の半径方向力と, それから永久 磁石起因を除いたものを図6に示す. 図6から,ティ 一ス(2)の半径方向力は, 電気角 $0 \sim 60^{\circ}, 180 \sim 240^{\circ}$ では，ほとんど電流起因であることがわかる．

ここで, 次の 3ケース (1)右辺 3項まで考虑, (2) 6 項まで考虑, (3)7 項まで考虑) で式(1)の妥当性を検討 する. 結果を電流起因半径方向力とともに図 7,8 に 示す. 図 7 は基本電流を $900 \mathrm{~A}$ としたもので, ケース (1)では半径方向力を表せていない. ケース(2)はかなり よく半径方向力を表しているが, ケース(3)のほうがさ

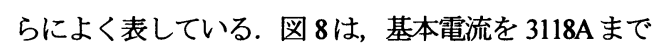
上げた場合の半径方向力で式(1)の妥当性を検討した ものである. $900 \mathrm{~A}$ 同様, 7 項まで考慮したケース(3)が 最もよく一致している.ここでは普遍性を考えて, 式 (1)の右辺 7 項までを考慮することにする.

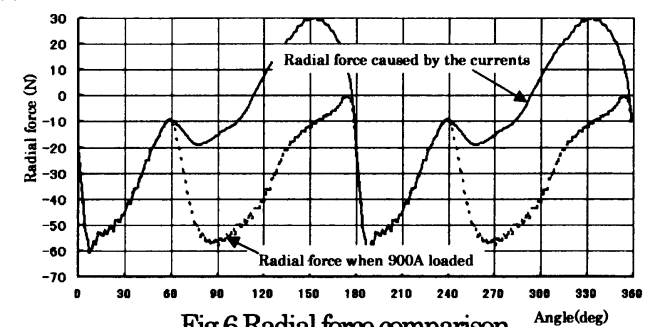

Fig.6 Radial force comparison Angle(deg)

\section{4 高次電流重量時の半径方向力の数式表現}

$\mathrm{U}, \mathrm{V}, \mathrm{W}$ 相の基本電流を $I_{u}, I_{v}, I_{w}$ として, $\mathrm{p}$ 次の高 次電流を重睤した印加電流 $I_{u}^{\prime}, I_{v}^{\prime}, I_{w}^{\prime}$ '次式で与える のことを考える。

$$
\begin{aligned}
& I_{u}{ }^{\prime}=(1+q \cos p \theta+r \sin p \theta) I_{u} \\
& I_{v}{ }^{\prime}=(1+q \cos p \theta+r \sin p \theta) I_{v} \\
& I_{w}{ }^{\prime}=(1+q \cos p \theta+r \sin p \theta) I_{w}
\end{aligned}
$$

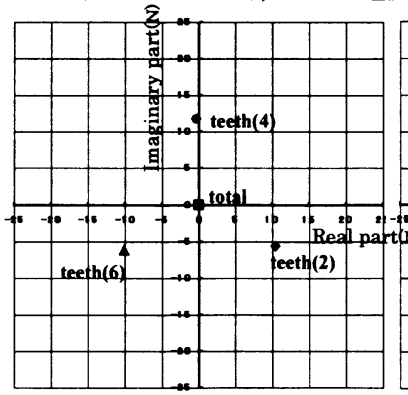

(a) Second order

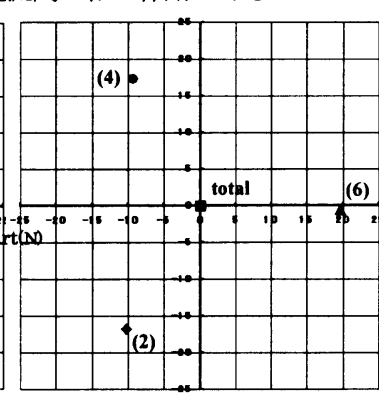

(b) Fourth order

Fig.5 The phase of radial oscillating force on teeth

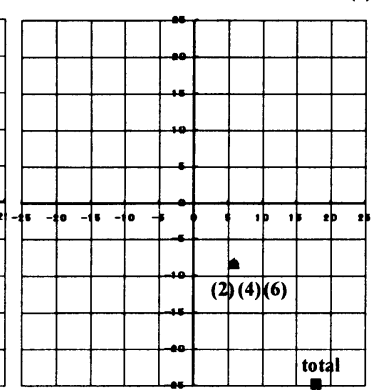

(c) Sixth order 
変化しないとすると, 高次電流重畳時の半径方向力 $F$ $\left(I_{u}, I_{v}, I_{w}\right)^{\prime}$ は, 式(1)において $I_{u}$ などの代わりに $I_{u}{ }^{2}$ など として，式(2)を式(1)に代入すると，

$$
\begin{aligned}
& F\left(I_{u}, I_{v}, I_{w}\right)^{\prime}=F\left(I_{u}, I_{v}, I_{w}\right) \\
& \quad+\left(S_{1}+2 S_{2}+3 S_{3}\right)(q \cos p \theta+r \sin p \theta)
\end{aligned}
$$

なお, 式(3)を求める過程で $q, r$ は微小としてテー ラー展開一次までを採用している.

ただし,

$$
\begin{aligned}
& S_{1}=G_{u} I_{u}+G_{v} I_{v}+G_{w} I_{w} \\
& S_{2}=G_{u v} I_{u} I_{v}+G_{v w} I_{v} I_{w}+G_{w u} I_{w} I_{u} \\
& S_{3}=G_{u v w} I_{u} I_{v} I_{w}
\end{aligned}
$$

高次電流重盢による半径方向力は, 式(3)の右辺第二 項の形で現れる.

\section{3. 高次電流の定式化}

ここでは, 高次電流により発生する半径方向力に より, オリジナルの半径方向力（電流起因と永久磁石 起因の両者を含む. 図 3 下図に対応）のp次高調波成 分を低减する方法を述べる. オリジナルの半径方向力 の $p$ 次高調波成分を $F_{p}$ とすると, 式(3)から, $\left(S_{1}+2 S_{2}+3 S_{3}\right)(q \cos p \theta+r \sin p \theta)=-F_{p}$
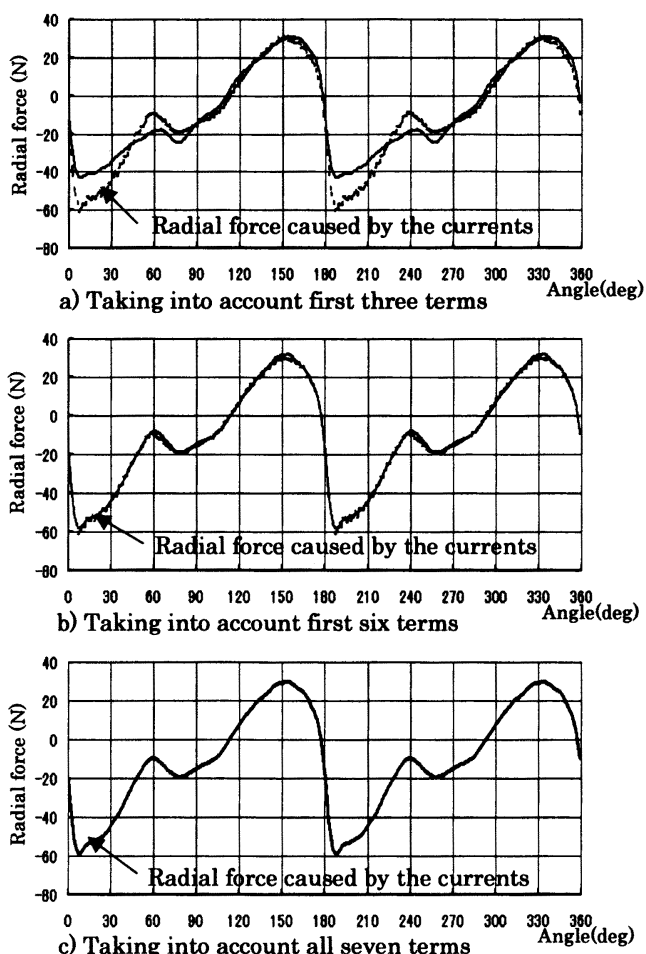

Fig.7 Verification of equation (1) for $900 \mathrm{~A}$
を満たす $q, r$ が $p$ 次高調波成分を低减することにな る. 式(5)から， $S_{1}, S_{2}, S_{3}$ の $p$ 次に関係する項は， 0 次と $2 p$ 次になる. しかし, 式(4)で示される $S_{1}, S_{2}$, $S_{3}$ の $G_{u}, G_{v} \cdots, G_{u w}$ をフーリエ級数で表現すると, 高次ほど小さくなるので, ここでは $2 p$ 次は無視して, 0次の項のみを考虑する.

いま, ある関数 $\mathrm{Y}(\theta)$ の 0 次近似項（平均值）を YlDCで表すと,

$$
\begin{aligned}
{\left[S_{1}+\right.} & \left.2 S_{2}+3 S_{3}\right]\left.\right|_{D C}=\left[3 F\left(I_{u}, I_{v}, I_{w}\right)\right. \\
- & \left.F\left(I_{u}, I_{v}, 0\right)-F\left(0, I_{v}, I_{w}\right)-F\left(I_{u}, 0, I_{w}\right)\right]\left.\right|_{D C} \\
= & {\left[\left\{F\left(I_{u}, I_{v}, I_{w}\right)-F\left(I_{u}, I_{v}, 0\right)\right\}\right.} \\
& +\left\{F\left(I_{u}, I_{v}, I_{w}\right)-F\left(0, I_{v}, I_{w}\right)\right\} \\
& \left.+\left\{F\left(I_{u}, I_{v}, I_{w}\right)-F\left(I_{u}, 0, I_{w}\right)\right\}\right]\left.\right|_{D C}
\end{aligned}
$$

となるので, $F_{p}$ をフーリエ変換したときの実部を $F_{p}^{\text {ndd }}$, 虚部を $F_{p}^{\text {mag }}$ とすると， $q, r$ はそれぞれ，

$$
\begin{gathered}
q=-F_{p}{ }^{\text {real }} /\left(\left.S_{1}\right|_{D C}+\left.2 S_{2}\right|_{D C}+\left.3 S_{3}\right|_{D C}\right) \\
r=-F_{p}{ }^{{ }^{\text {mag }}} /\left(\left.S_{1}\right|_{D C}+\left.2 S_{2}\right|_{D C}+\left.3 S_{3}\right|_{D C}\right)
\end{gathered}
$$

式(の）三相同時に印加したときの半径方向力と 二相を同時に印加したときの半径方向力の差をとって 加算したものの 0 次を意味しており， $S_{1}$ を求めるに必 要であった $I_{u}$ 相のみ印加などの単相印加の計算は， $q$,
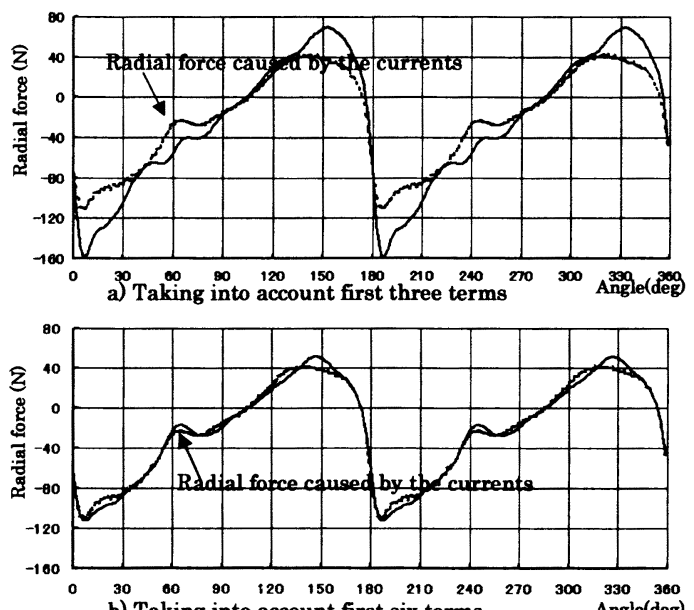

b) Taking into account first six terms

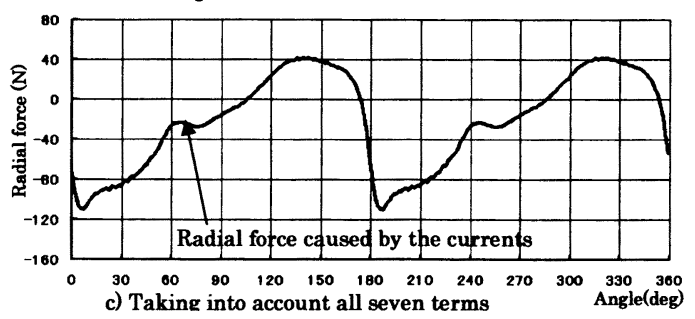

Fig.8 Verification of equation (1) for 3118A 
$r$ を求めるには不要である. また, 式(7), (8)から, $q, r$ には

$$
\frac{r}{q}=F_{p}{ }^{i m a g} / F_{p}{ }^{\text {real }}
$$

の関係があるので, 式(の測定に手間がかかる実験 では, 式(9)の関係を維持して $q, r$ を変化させ最適 な $q, r$ を探る方法が有効と思われる.

\section{4. 高次電流重量による加振力の低減}

\section{1 高次電流の重且効果 ここでは, 22 節で検} 討した 6 の整数倍次数のうち，12 次を対象に，その 低减を検討する. すなわち, 式(2)で $p=12$ とし, 式(7), (8)の $q, r$ を求めた（結果を $q_{0} ， r_{0}$ とする）。 そ の結果の三相交流 $I_{u}, \quad I_{v}^{\prime}, I_{v}^{\prime}$ を $900 \mathrm{~A}$ の基本電流とと もに図9に示す.この場合， $q_{0}=0.12 ， r_{0}=-0.23$ だっ たので, 重畳した高次電流は基本電流に対して約 $26 \%$ の電流值になっている. $p=12$ の場合, 式(2)加高次 電流は 11 次, 13 次成分を有していることになるので, 高次電流の振幅変調は 1 周期に 2 回あり, それらが基 本電流の山, 谷で大きく発現している.

また, この三相交流を印加した場合の有限要素法 磁界解析結果のティース(2)の半径方向力を, オリジ ナルの半径方向力とともに図 10 に示す. ティース(2) の半径方向力は, ロータ中心向きに電気角約 $10^{\circ}$, $90^{\circ}, 190^{\circ}, 270^{\circ}$ にピーク (中心向き, マイナス)

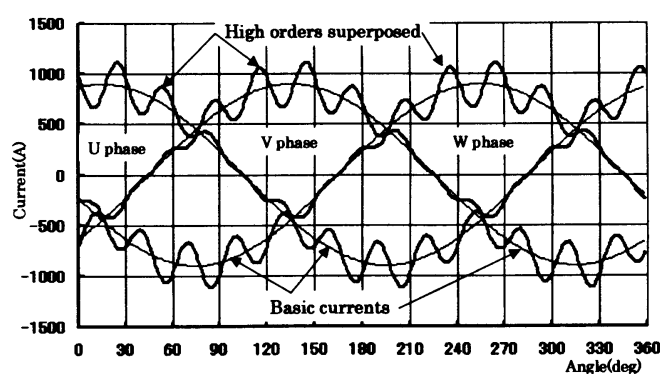

Fig.9 Three phase alternating currents including a high order one

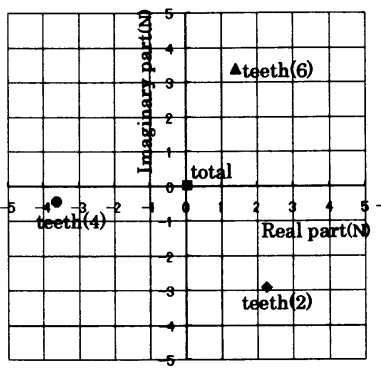

(a) 10th order

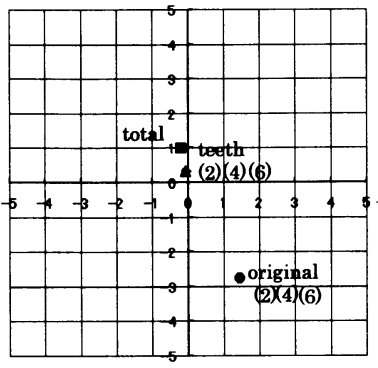

(b) 12th order
を持っている. 図 6 から, 電気角約 $10^{\circ}, 190^{\circ}$ は電

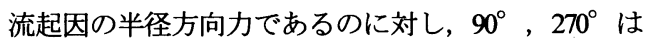
主として永久磁石によるものである. 有限要素法磁界 解析結果の磁束の流机によると, 電気角約 $10^{\circ}$ では, 磁束はロータ永久磁石間鉄部 $\rightarrow$ ティース(6) $\rightarrow$ ステー タバックヨークーティース(2)↔ロータ永久磁石間鉄 部一と流れており, 電気角約 $190^{\circ}$ では逆の流れにな っている. この磁束の流れは, 図 2よりティース(6)に 関連して U 相電流で引起こされているものと考えら れる. その結果, U 相の重畳電流が大きく発現してい る電気角区間において，図10 のようにティース(2)の 半径方向力はオリジナルとの差が大きくなっていると 考えられる. 一方, 永久磁石が主要因の電気角 $90^{\circ}$, $270^{\circ}$ では, 高次電流の影響は小さく, 両者の差はあ まり大きくない. 高次電流重畳時のティース(2)の半 径方向力をフーリエ変換した結果をデシベル表示した ものをオリジナルのフーリエ変換結果とともに図 11 に示す. 12 次成分は $19.6 \mathrm{~dB}$ 低减している. なお, 平 均トルクは, 高次電流重畳前の $65.75 \mathrm{Nm}$ に対して

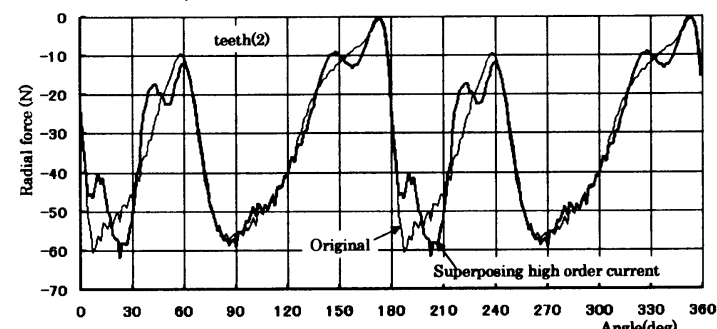

Fig.10 Comparing the resultant radial force

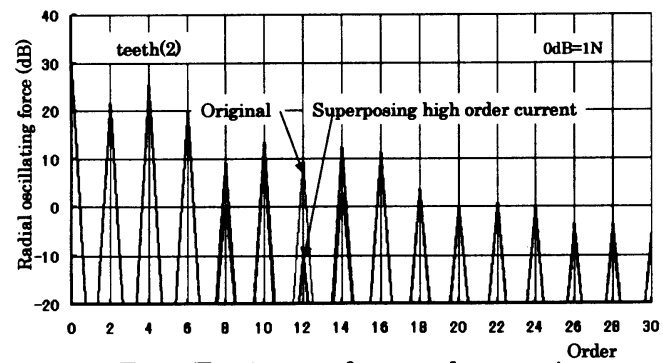

Fig.11 Fourier transform result comparison

Fig.12 The phase of radial oscillating force on teeth in case of superposing a high current 
$1.82 \mathrm{Nm}$ (約 $2.8 \%$ ) 大きくなった.

また, 6 の整数倍次数以外の次数として 10 次, 14 次について，各ティースの位相関係を調べた結果を， 低减対象とした 12 次とともに図 12 に示寸. 10 次, 14 次の合力はほぼ 0 となっており，6の整数倍次数以外 の偶数次数の加振力は, 円環 0 次モードを励起しにく い状態が高次電流重畳後も保持されていると考えられ る. また, 12 次は, 狙い通り各ティースにおける加 振力の絶対值が小さくなっている.

\section{2 重畳する高次電流を変化させたときの効果}

高次電流の定式化過程ではテーラー展開一次近似を採 用したり， $S_{1}, S_{2}, S_{3}$ の $2 p$ 次を無視したり, 高次電流 重疊時に式(1)の $G_{u}, G_{v}, \cdots$ は変化しないと仮定する などの近似が入っているので，前節で得られた $q_{0}$, $r_{0}$ が，対象とする加振力に対して最も大きい効果を もたらすとはかぎらない. そこで, 得られた $q_{0}, r_{0}$ 近傍で $q, r$ を変化させた高次電流を重畳して有限要 素法磁界解析をおこない, 加振力の低减効果を調べた. ティース(2)における 12 次成分低减効果を図 13 に示す. 定式化で得られた $q_{0}=0.12, \quad r_{0}=-0.23$ に対して,$q$ $=0.11, \quad r=-0.20$ でさらに約 $5 \mathrm{~dB}$ の低减効果があった.

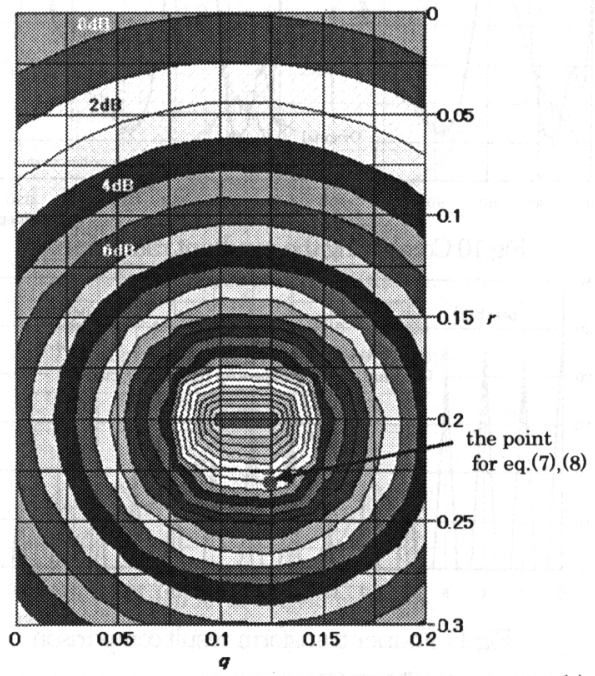

Fig.13 Reduction map of oscillating force on teeth(2)

\section{5. 結 論}

4極対 48 ティースの分布巻 IPM モ一夕を対象に，モ 一タケースからの放射音の主な要因である円環 0 次モ 一ドを励起する加振力を, 基本電流に高次電流を重畳 する方法で低减することを試みた，その結果，

（1）半径方向力は, 三相交流電流の 7 項多項式 で表現でき, 各項の係数は, 三相交流電流
を単独印加，二相同時印加，三相同時印加 したときの節点力を使って求めることがで きる。

（2）低減したい加振力の次数の \pm 1 次の次数を もった高次電流を基本電流に重畳すること で加振力の低減が可能である. 高次電流の 大きさは, 三相交流電流を同時に印加した ときと二相交流電流を同時に印加したとき の半径方向力の 0 次近似項（平均值）を使 って求めることができる.

（3）対象としたモータでは, 高次電流は基本電 流の約 26\%の大きさで, 加振力低减効果は 約 $20 \mathrm{~dB}$ であった。 また平均トルクは $2.8 \%$ 大きくなった.

（4）本手法で得られた高次電流の近傍にさらに 効果が大きい高次電流值が存在する場合も, 本手法で得られた高次電流を起点として, その高次電流を見出すことが容易である.

ここでは, 900A について論じたが, 他の電流でも同じ 手順を踏んで高次電流を導くことができる.

最後に，本論文を作成するにあたり，JMAG を使用 した磁界解析を実行していただいたゼネラルエンジニ アリング株の大机弘氏，NASTRAN を使用したステ 一タの固有值解析を実行していただいた弊社研究実験 試作部の小䛀洋二氏に感謝いたします。

\section{文献}

（1）塩幡宏規・根本佳奈子・名川泰正・坂本茂・小林孝 司・伊藤元哉・小原木春雄, 電磁力励起による電動 機の振動放射音解析法, 電学論 D, 118 巻 11 号, 1998 年

（2）石橋文徳・野田伸一, モ一夕の振動・騒音の解析, JMAGUsers Conferenc2002

（3）真田雅之 - 中田一聡・森本茂雄・武田洋次 - 山井広 之, 極内空隙による SR モータのラジアル力低减と低 騒音化, 電学論 $\mathrm{D}, 123$ 巻 12 号, 2003 年

（4）小林貴彦・馬雷 - 真田雅之 - 森本茂雄 - 武田洋次, 集中巻 IPMSM のラジアルカとトルクリプルの低减法, 電気学会回転譏械研究会資料 RM-02，41-51，2002

（5）浅野能成・本田幸夫・武田洋次・森本茂雄，集中巻 永久磁石同期モータのラジアル応力に着目した振動 低减，電学論 D, 121 巻 11 号, 2001 年

（6）屋代春樹・高田一，高次電流重畳による電動機の卜 ルクリプル低减。機論, 72 巻 714 号, C (2006), 435-440

（7）三浦徹也，公開特許公報(A)，P2001-352791A 